Buletin Peternakan Tropis

Bulletin of Tropical Animal Science

Doi: https://doi.org/10.31186/bpt.2.2.140-148
Bul. Pet. Trop. 2(2): 140-148, 2021

e-ISSN: $2722-0788$

p-ISSN: 2722-1733

\title{
Pemberian Tepung Katuk dan Dampaknya Terhadap Parameter Mutu Karkas Ayam Kampung Betina
}

\author{
(Inclusion of Katuk Leaf Meal and Its Effects on Carcass Quality of Female Local Chicken)
}

Heri Dwi Putranto *, Nida' Fauziyyah Aziz, Urip Santoso, Kususiyah, Edi Soetrisno

Jurusan Peternakan, Fakultas Pertanian, Universitas Bengkulu Jl. WR. Supratman, Kandang Limun, Bengkulu 38371A

* Penulis Korespondensi : heri_dp@unib.ac.id

Dikirim (received): 02 September 2021; dinyatakan diterima (accepted): 26 Oktober 2021; terbit (published): 15 November 2021. Artikel ini dipublikasi secara daring pada https://ejournal.unib.ac.id/index.php/buletin_pt/index

\begin{abstract}
The objective of this experiment was to evaluate the effect of feeding katuk leaf meal on carcass parameters of female local chickens. The research was conducted from August to October 2020 located in Commercial Zone and Animal Laboratory (CZAL) and Laboratory of Animal Science Department, Faculty of Agriculture, University of Bengkulu. The research treatments were four levels of Katuk leaf meal in the rations (P0: $0 \%, \mathrm{P} 1: 4 \%, \mathrm{P} 2: 8 \%$, and $\mathrm{P} 3: 12 \%)$. The local chickens were slaughtered, and the carcass quality measurements were conducted. Feeding Katuk leaf meal showed insignificant effects on slaughter weight, carcass weight, dressing percentage, carcass color, meat bone ratio, cooking loss and drip loss ( $P>0.05$ ). To sum up, inclusion of $0,4,8$ and $12 \%$ of Katuk leaf meals in the ration did not affect carcass quality.
\end{abstract}

Key words: female local chicken, katuk leaf meal, carcass quality

\section{ABSTRAK}

Penelitian ini bertujuan untuk mengetahui Pemberian Tepung Katuk dan Dampaknya Terhadap Parameter Mutu karkas Ayam Kampung Betina. Penelitian ini dilakukan selama 3 bulan terhitung dari bulan Agustus hingga Oktober 2020 yang berlokasi di Commercial Zone and Animal Laboratory (CZAL) dan Laboratorium Jurusan Peternakan Fakultas Pertanian Universitas Bengkulu. Rancangan penelitian yang digunakan adalah Rancangan Acak Lengkap (RAL), terdiri atas 4 perlakuan dengan 10 ekor ayam kampung betina sebagai ulangan perpelakuan, $\mathrm{PO}=0 \%$ tepung daun katuk, $\mathrm{P} 1=4 \%$ tepung daun katuk, $\mathrm{P} 2=8 \%$ tepung daun katuk, $\mathrm{P} 3=12 \%$ tepung daun katuk. Parameter mutu karkas yang diamati pada penelitian ini yaitu bobot potong, bobot karkas, persentase karkas, warna Karkas, meat bone ratio, cooking loss dan drip loss. Hasil yang didapat dalam penelitian menunjukan bahwa pemberian tepung daun katuk berpengaruh tidak nyata terhadap $(P>0.05)$ bobot potong, bobot karkas, persentase karkas, warna karkas, meat bone ratio, cooking loss dan drip loss pada ayam kampung betina. Kesimpulan yang dapat diambil yaitu perlakuan tidak mempengaruhi mutu karkas ayam kampung betina.

Kata kunci: ayam kampung, tepung katuk, mutu karkas

\section{PENDAHULUAN}

Ayam kampung atau ayam buras (bukan ras) merupakan jenis ternak unggas yang telah dikenal di seluruh pelosok negeri dan telah diternakkan sebagai penghasil daging, telur ataupun sebagai hiburan. Sebagai penghasil daging, salah satu hal yang perlu diperhatikan adalah karkasnya. Karkas adalah bagian tubuh ayam yang disembelih lalu dikeluarkan isi perut, kaki, leher, kepala, bulu dan darah. Karkas yang dihasilkan ayam 
kampung memiliki rasa yang enak dan gurih, tetapi juga dikenal dengan daging yang lebih alot daripada daging ayam broiler. Salah satu cara untuk mengoptimalkan produksi dan kualitas karkas pada ayam adalah dengan memberikan feed suplement. Upaya lain untuk meningkatkan produktivitas ayam kampung adalah memberikan ransum dengan imbangan energi dan protein yang baik berdasarkan keseimbangan protein dan energi metabolis sesuai kebutuhan, karena fungsi dari pakan yang diberikan ke ayam pada prinsipnya adalah untuk memenuhi kebutuhan pokok untuk hidup, membentuk sel-sel dan jaringan tubuh, dan selanjutnya dipakai untuk keperluan berproduksi (Adnyana et al., 2014).

Katuk (Sauropus androgynus L. Merr) merupakan salah satu tanaman obat-obatan tradisional yang mempunyai nilai zat gizi tinggi, senyawa antibakteri, antioksidan dan juga mengandung $\beta$-karoten yang tinggi. $\beta$ karoten merupakan pigmen yang berperan dalam peningkatan warna kuning pada karkas sehingga penambahan daun katuk akan meningkatkan warna karkas. Menurut Azis dan Muktiningsih (2006) kandungan zat makanan yang terdapat dalam $100 \mathrm{~g}$ katuk yaitu kalori $59 \mathrm{kal}$, protein 6,4 g, lemak $1 \mathrm{~g}$, hidrat arang $9,9 \mathrm{~g}$, serat $1,5 \mathrm{~g}$, abu $1,7 \mathrm{~g}$, kalsium $233 \mathrm{mg}$, phosphor $98 \mathrm{mg}$, besi $3,5 \mathrm{mg}$, karoten $10.020 \mu \mathrm{g}$, vitamin B dan C $164 \mathrm{mg}$ dan air $81 \mathrm{~g}$.

Agustal et al. (1997) menemukan enam komponen utama senyawa aktif di dalam daun katuk diantaranya yaitu Monomethyl succinate, 2-Phenylmaloric acid, Cyclopentanol, 2-metyl-acetate, Benzoic acid, 2- pyrolidinone dan methylpyroglutamat. Senyawa-senyawa ini mampu berperan sebagai senyawa eksogenus yang dapat berpartisipasi dalam metabolisme karbohidrat, protein dan lemak (Suprayogi 2000) sehingga terjadi peningkatan massa otot dan mengurangi deposisi lemak.

Menurut Letis (2016) pemberian sediaan Ekstrak Katuk Kering 17,07 g/kg, Ekstrak katuk seduh 9,63 g/kg dan perasan katuk 34,68 g/ kg mampu meningkatkan kualitas karkas dan mencegah penurunan produktivitas pertambahan berat badan ayam broiler dibandingkan dengan sediaan tepung daun katuk yang nyata dapat menurunkan berat badan badan ayam broiler. Menurut Subekti (2003) menyatakan bahwa pemberian tepung daun katuk sampai $9 \%$ dalam ransum mampu meningkatkan kualitas telur dan karkas ayam lokal.

Marsetyo (2015) menyatakan bahwa pemberian daun katuk sebagai komponen ransum ayam kampung dengan level $10 \%$, dapat meningkatkan konsumsi ransum, pertambahan bobot badan dan persentase karkas. Penelitian yang dilakukan Syahruddin et al. (2013) pemberian fermentasi daun katuk pada dosis $2 \%, 4 \%, 6 \%, 8 \%, 10 \%, 12 \%$, dan $14 \%$ terhadap karkas broiler, mengakibatkan peningkatan berat badan dan konsumsi, tetapi terjadi penurunan persentase karkas. Bidura et al. (2007) melaporkan bahwa pertambahan bobot badan dan efisiensi penggunaan ransum ayam broiler meningkat seiring dengan pemberian kombinasi daun katuk $(1,5 \%)$ dan bawang putih $(1,5 \%)$ dalam ransum ayam broiler.

Mencermati hal tersebut, pemberian tepung daun katuk dalam ransum dapat memperbaiki kualitas karkas ayam kampung. Penelitian ini dimaksudkan untuk menguji pemberian tepung daun katuk terhadap kualitas karkas pada ayam kampung.

Penelitian ini bertujuan untuk mengevaluasi pemberian tepung katuk dan dampaknya terhadap parameter mutu karkas ayam kampung betina.

\section{METODE PENELITIAN}

Penelitian telah dilakukan selama 3 bulan mulai bulan Agustus - Oktober 2020 di Commercial Zone and Animal Laboratory (CZAL) sebagai tempat dilakukannya perlakuan pada ternak dan Laboratorium Jurusan Peternakan Fakultas Pertanian Universitas Bengkulu sebagai tempat 
pengamatan sampel berat potong, berat karkas, persentase karkas, warna karkas, meat bone ratio, cooking loss dan drip loss pada ayam kampung.

\section{Pembuatan Tepung Daun Katuk}

Proses pembuatan tepung daun katuk diawali dengan mengeringkan daun katuk kemudian, daun katuk dikering anginkan pada suhu ruangan selama $3 \times 24$ jam. Setelah itu dilanjutkan dengan penjemuran daun katuk di bawah sinar matahari selama 6 - 8 jam sampai daun kering. Tahapan selanjutnya yaitu daun katuk dipisahkan antara daun dan batangnya. Pembuatan tepung daun katuk menggunakan bagian daun saja. Bagian daun digiling menggunakan mesin giling sampai menjadi tepung siap pakai.

\section{Persiapan Kandang}

Satu minggu sebelum penelitian dilaksanakan, kandang dan peralatan penunjang dibersihkan dan disemprot dengan desinfektan terlebih dahulu sebelum ternak dimasukan ke kandang. Hal ini dilakukan untuk mencegah timbulnya bibit penyakit. Kandang yang digunakan selama perlakuan merupakan kandang individu tipe litter sebanyak 40 buah.

\section{Pemeliharaan}

Penelitian ini menggunakan 40 ekor ayam kampung umur 32 - 34 minggu dilakukan pemeliharaan dalam penelitian selama 8 minggu. Pemeliharaan Ayam dilakukan secara individu pada kandang litter. Pemberian pakan dilakukan dua kali dalam sehari yaitu pagi dan sore hari sebanyak $150 \mathrm{~g} / \mathrm{ekor} / \mathrm{hari}$ dan air minum yang diberikan ad libitum.

\section{Pengambilan Sampel}

Setelah 8 minggu perlakuan dilakukan pemanenan. Setiap perlakuan dilakukan penyembelihan. Sebelum dilakukan penyembelihan, ayam dipuasakan terlebih dahulu selama 12 jam. Pengamatan terhadap parameter mutu karkas dilakukan sesuai dengan prosedur pengambilan data sampel pada masing-masing ayam.

\section{Rancangan Penelitian}

Penelitian menggunakan 40 ekor ayam kampung betina umur 32 - 34 minggu dengan 4 perlakuan dan 10 ulangan. Perlakuan yang digunakan sebagai berikut :

$\mathrm{PO}=0 \%$ pemberian tepung daun katuk (Kontrol)

$\mathrm{P} 1=4 \%$ pemberian tepung daun katuk

$\mathrm{P} 2=8 \%$ pemberian tepung daun katuk

$\mathrm{P} 3=12 \%$ pemberian tepung daun katuk

\section{Analisis Data}

Data yang diperoleh dianalisis dengan menggunakan ANOVA jika hasil analisis berpengaruh nyata $(P<0,05)$ maka diuji lanjut dengan menggunakan Duncan's Multiple Range Test (DMRT).

\section{HASIL DAN PEMBAHASAN}

\section{Berat Potong}

Hasil analisis ragam menunjukkan bahwa pemberian tepung katuk dalam ransum berpengaruh tidak nyata terhadap berat potong ayam kampung $(P>0,05)$. Rataan berat potong perlakuan P0, P1, P2 dan P3 sebesar $1207,04 \mathrm{~g}, 1341,94 \mathrm{~g}, 1333,26 \mathrm{~g}$ dan 1236,86 g. Kurang meningkatnya berat potong secara nyata menunjukkan bahwa jumlah senyawa aktif dalam daun katuk yang dikonsumsi oleh ayam kampung kurang memadai. Hasil analisis pengaruh pemberian tepung daun katuk terhadap berat potong ayam kampung disajikan pada Tabel 1.

Hal ini terjadi karena penelitian ini menggunakan spesies, umur, zat gizi dan lingkungan ayam dibuat hampir sama sehingga perlakuan tidak menghasilkan pengaruh yang nyata terhadap berat potong ayam kampung. Rasyaf (2000) menyatakan berat potong pada ayam dapat dipengaruhi oleh spesies, umur, berat badan, temperatur lingkungan dan tingkat gizi dalam pakan.

Marsetyo (2015) menyatakan bahwa pemberian tepung daun katuk pada level $10 \%$ 
memberikan hasil terbaik pada berat akhir ayam kampung umur 8 minggu. Menurut Letis (2016) berat badan akhir ayam broiler perlakuan tepung daun katuk (TDK) sebanyak $50 \mathrm{~g} / \mathrm{kg}$ memiliki rataan terendah dibandingkan pemberian sediaan ekstrak katuk kering (EKK) sebanyak $17.07 \mathrm{~g} / \mathrm{kg}$, ekstrak katuk seduh (EKS) $9.63 \mathrm{~g} / \mathrm{kg}$ dan katuk perasan (KP) $34.68 \mathrm{~g} / \mathrm{kg}$ karena peran senyawa aktif yang terdapat dalam sediaan tersebut memiliki potensi dalam peningkatan pertumbuhan dibandingkan sediaan tepung daun katuk.

\section{Berat Karkas}

Hasil analisis ragam menunjukkan bahwa pemberian tepung daun katuk berpengaruh tidak nyata terhadap berat karkas $(P>0.05)$. Rataan berat karkas perlakuan P0, P1, P2 dan P3 sebesar 736,25 g, 766,40 g, 800,03 g dan
757,39 g. Hal ini terjadi karena berat potong yang dihasilkan juga menunjukkan hasil tidak nyata Menurut Letis (2016) berat badan akhir ayam broiler perlakuan tepung daun katuk (TDK) sebanyak $50 \mathrm{~g} / \mathrm{kg}$ memiliki rataan terendah dibandingkan pemberian sediaan ekstrak katuk kering (EKK) sebanyak 17.07 $\mathrm{g} / \mathrm{kg}$, ekstrak katuk seduh (EKS) $9.63 \mathrm{~g} / \mathrm{kg}$ dan katuk perasan (KP) $34.68 \mathrm{~g} / \mathrm{kg}$ karena peran senyawa aktif yang terdapat dalam sediaan tersebut memiliki potensi dalam peningkatan pertumbuhan dibandingkan sediaan tepung daun katuk. sebagaimana yang dikemukakan oleh Ahmad dan Herman (1982) bahwa berat karkas yang dihasilkan sejalan dengan berat hidup, semakin tinggi berat hidup maka berat karkas yang dihasilkan semakin tinggi.

Berdasarkan hasil penelitian pemberian tepung daun katuk dalam ransum terhadap berat karkas ayam kampung memberikan hasil

Tabel 1. Pengaruh pemberian tepung daun katuk terhadap berat potong

\begin{tabular}{|c|c|c|c|c|c|c|}
\hline \multirow{2}{*}{ Perlakuan } & \multicolumn{5}{|c|}{ Ulangan } & \multirow{2}{*}{ Rata-Rata \pm SD } \\
\hline & U1 & U2 & U3 & U4 & U5 & \\
\hline \multicolumn{7}{|c|}{$\ldots g \ldots$} \\
\hline PO & 1107,30 & 1390,10 & 1258,30 & 1196,00 & 1083,50 & $1207,04 \pm 123,97$ \\
\hline P1 & 1358,50 & 1316,00 & 1166,40 & 1366,80 & 1502,00 & $1341,94 \pm 120,41$ \\
\hline $\mathrm{P} 2$ & 861,40 & 1335,10 & 1690,50 & 1482,90 & 1296,40 & $1333,26 \pm 305,79$ \\
\hline P3 & 891,70 & 1143,50 & 1330,80 & 1441,80 & 1376,50 & $1236,86 \pm 222,58$ \\
\hline Probabilitas & & & & & & 0,67 \\
\hline
\end{tabular}

Tabel 2. Pengaruh Pemberian tepung daun katuk terhadap berat karkas

\begin{tabular}{ccccccc}
\hline \multirow{2}{*}{ Perlakuan } & \multicolumn{5}{c}{ Ulangan } & \multirow{2}{*}{ Rata-Rata \pm Sd } \\
\cline { 2 - 5 } & U1 & U2 & U3 & U4 & U5 & \\
\hline & & & $\ldots . \ldots$ & & & \\
P0 & 642,48 & 843,19 & 767,12 & 751,33 & 677,11 & $736,25 \pm 78,91$ \\
P1 & 861,90 & 782,96 & 684,64 & 672,51 & 830,00 & $766,40 \pm 85,06$ \\
P2 & 506,75 & 789,77 & 101,14 & 900,21 & 793,30 & $800,03 \pm 187,31$ \\
P3 & 544,05 & 768,32 & 805,89 & 805,92 & 862,75 & $757,39 \pm 123,94$ \\
\hline Probabilitas & & & & & 0,88 \\
\hline
\end{tabular}

Keterangan: $\mathrm{P} 0=0 \%$ pemberian tepung daun katuk (kontrol), $\mathrm{P} 1=4 \%$ pemberian tepung daun katuk, $\mathrm{P} 2=8 \%$ pemberian tepung daun katuk, $\mathrm{P} 3=12 \%$ pemberian tepung daun katuk 
paling bagus pada taraf $8 \%$. Hasil penelitian Santoso et al. (2015) pemberian daun katuk yang difermentasi dengan berbagai fermentor berpengaruh tidak nyata terhadap persentase karkas. Qotimah et al. (2014) menyatakan bahwa pemberian ekstrak daun katuk memberikan pengaruh tidak nyata terhadap berat karkas. Karkas merupakan organ tubuh yang masak lambat, sehingga dengan bertambahnya umur maka pertumbuhannya semakin bertambah dan Hasil analisis pengaruh pemberian tepung daun katuk terhadap berat karkas ayam kampung disajikan pada Tabel 2.

Berdasarkann hasill penelitian pemberian tepung daun katuk dalam ransum terhadap berat karkas ayamm0kampung memberikan hasil paling bagus pada taraf $8 \%$. Hasil penelitian Santoso et al. (2015) pemberian daun katuk yang difermentasi dengan berbagai fermentor berpengaruh tidak nyata terhadap persentase karkas. Qotimah et al. (2014) menyatakan bahwa pemberian ekstrak daun katuk memberikan pengaruh tidaknnyata terhadap berat karkas. Karkas merupakan salah satu organ tubuh yang masak lambat, sehinggaMdengan bertambahnya umur maka pertumbuhannya semakin bertambah dan persentase terhadap bobot hidup juga meningkat (Matitaputty et al., 2011). Tamzil et al. (2015) menyebutkan selain umur, strain ayam dapat mempengaruhi bobot hidup pada ayam.

\section{Persentase Karkas}

Hasil analisis pengaruh pemberian tepung daun katuk terhadap persentase karkas ayam kampung disajikan pada Tabel 3. Hasil Analisis ragam menunjukkan bahwa pemberian pemberian tepung daun katuk berpengaruh tidak nyata terhadap persentase karkas $(P>$ 0.05). Rataan persentase karkas perlakuan $\mathrm{PO}$,

Tabel 3. Pengaruh pemberian tepung daun katuk terhadap perentase karkas

\begin{tabular}{ccccccc}
\hline \multirow{2}{*}{ Perlakuan } & \multicolumn{5}{c}{ Ulangan } & Rata-rata \pm SD \\
\cline { 2 - 5 } & U1 & U2 & U3 & U4 & U5 & \\
\hline & & $\ldots \% \ldots$ & & \\
P0 & 58,02 & 60,66 & 60,96 & 62,82 & 62,49 & $60,99 \pm 1,91$ \\
P1 & 63,44 & 59,50 & 58,70 & 49,20 & 55,26 & $57,22 \pm 5,34$ \\
P2 & 58,83 & 59,15 & 59,75 & 60,71 & 61,19 & $59,93 \pm 1,01$ \\
P3 & 61,01 & 67,19 & 60,56 & 55,90 & 62,68 & $61,47 \pm 4,07$ \\
\hline Probabilitas & & & & & 0,270
\end{tabular}

Keterangan : $\mathrm{PO}=0 \%$ pemberian tepung daun katuk (kontrol), $\mathrm{P} 1=4 \%$ pemberian tepung daun katuk, P2 = 8\% pemberian tepung daun katuk, P3 = 12\% pemberian tepung daun katuk

Tabel 4. Pengaruh pemberian tepung daun katuk terhadap warna karkas

\begin{tabular}{ccccccc}
\hline \multirow{2}{*}{ Perlakuan } & \multicolumn{5}{c}{ Ulangan } & \multirow{2}{*}{ Rata-rata \pm SD } \\
\cline { 2 - 5 } & U1 & U2 & U3 & U4 & U5 & \\
\hline P0 & 102,00 & 103,00 & 103,00 & 103,00 & 103,00 & $102,80 \pm 0,45$ \\
P1 & 104,00 & 104,00 & 102,00 & 102,00 & 104,00 & $103,20 \pm 1,10$ \\
P2 & 102,00 & 104,00 & 103,00 & 104,00 & 104,00 & $103,40 \pm 0,89$ \\
P3 & 103,00 & 104,00 & 102,00 & 104,00 & 104,00 & $103,40 \pm 0,89$ \\
\hline
\end{tabular}

Probabilitas

0,67

Keterangan : $\mathrm{P0}=0 \%$ pemberian tepung daun katuk (kontrol), $\mathrm{P} 1=4 \%$ pemberian tepung daun katuk, P2 = 8\% pemberian tepung daun katuk, P3 = 12\% pemberian tepung daun katuk 
P1, P2 dan P3 sebesar 60,99 \%, 57,22 \%, $59,93 \%$ dan $61,47 \%$. Hal ini dikarenakan bobot potong dan karkas yang di dapat berpengaruh tidak nyata. Soeparno (2005) mengatakan bahwa salah satu faktor yang mempengaruhi persentase karkas adalah berat hidupnya. Menurut Marsetyo et al. (2015) pengaruh level penggunaan daun katuk (Sauropus androgynus) pada ransum terhadap penampilan produksi dan persentase karkas ayam kampung memiliki nilai kisaran 59\%$61,84 \%$.

Menurut Subeki et al. (2003) faktor yang dapat mempengaruhi persentase karkas adalah bangsa, umur, jenis kelamin, pakan, kondisi fisik dan lemak abdominal.

\section{Warna Karkas}

Hasil analisis pengaruh pemberian tepung daun katuk terhadap warna karkas ayam kampung disajikan pada Tabel 4.

Analisis ragam menunjukkan bahwa pemberian pemberian tepung daun katuk berpengaruh tidak nyata terhadap warna karkas ayam kampung $(P>0,05)$. Rataan P0 memiliki nilai rataan terendah yaitu 102,80 diikuti dengan P1 dengan nilai rataan 103,20 serta nilai rataan $\mathrm{P} 2$ dan $\mathrm{P} 3$ mendapat nilai rataan tertinggi yaitu 103,40 . Dibandingkan dengan PO (kontrol) rataan warna karkas pada P1 mempunyai warna karkas lebih tinggi sebanyak 0,39\%, sedangkan pada perlakuan P2 dan P3 mempunyai warna karkas sama yaitu $0,58 \%$ lebih tinggi dari pada PO. Adanya peningkatan skor warna karkas ayam kampung seiring dengan peningkatan kandungan tepung daun katuk sehingga diakibatkan oleh kandungan $\beta$-karoten yang ada pada daun katuk merupakan zat pemberi warna pada karkas. $\beta$-karoten merupakan faktor penentu lebih kuningnya warna pada karkas sehingga dapat mempengaruhi kualitas warna pada karkas ayam (Santoso et al., 2015).

\section{Meat Bone Ratio ( MBR)}

Hasil analisis ragam menunjukkan bahwa perlakuan pemberian tepung daun katuk tidak berpengaruh nyata terhadap meat bone ratio $(P>0.05)$. Salah satu faktor yang mempengaruhi meat bone ratio adalah protein dimana rendahnya konsumsi protein akan berpengaruh terhadap pertumbuhan jaringan dan pertumbuhan jaringan yang terhambat akan berpengaruh terhadap pembentukan daging (Nurkhasanah, 2017). Secara umum nilai meat bone ratio pada ayam sejalan dengan nilai berat karkas karena pembentukkan daging karkas yang tinggi akan mengakibatkan pembentukan tulang menjadi rendah sehingga nilai rasio daging terhadap tulang semakin tinggi. Nilai meat bone ratio yang didapat pada penelitian ini lebih rendah dari pada nilai meat bone ratio ayam buras umur 12 minggu yang diberikan perlakuan tepung daun senduduk yaitu 6,52-8,28 (Saputro, 2019). Hasil analisis pengaruh pemberian tepung daun katuk terhadap meat bone ratio ayam kampung disajikan Tabel 5 .

Tabel 5. Pengaruh pemberian tepung daun katuk terhadap meat bone ratio

\begin{tabular}{ccccccc}
\hline \multirow{2}{*}{ Perlakuan } & \multicolumn{5}{c}{ Ulangan } & Rata-Rata \pm Sd \\
\cline { 2 - 5 } & U1 & U2 & U3 & U4 & U5 & $5,42 \pm 0,90$ \\
P0 & 5,85 & 5,22 & 3,94 & 5,91 & 6,18 & $6,10 \pm 0,83$ \\
P1 & 6,66 & 6,66 & 6,34 & 4,66 & 6,18 & $5,37 \pm 1,38$ \\
P2 & 3,56 & 4,52 & 7,10 & 6,15 & 5,53 & $5,49 \pm 0,90$ \\
P3 & 5,96 & 6,15 & 4,86 & 4,22 & 6,24 & \\
\hline
\end{tabular}

$\begin{array}{ll}\text { Probabilitas } & 0,65\end{array}$

Keterangan : $\mathrm{PO}=0 \%$ pemberian tepung daun katuk (kontrol), $\mathrm{P} 1=4 \%$ pemberian tepung daun katuk, $\mathrm{P} 2=8 \%$ pemberian tepung daun katuk, $\mathrm{P} 3=12 \%$ pemberian tepung daun katuk. 
Tabel 6. Pengaruh pemberian tepung daun katuk terhadap cooking loss

\begin{tabular}{ccccccc}
\hline \multirow{2}{*}{ Perlakuan } & \multicolumn{7}{c}{ Ulangan } & Rata-Rata \pm Sd \\
\cline { 2 - 5 } & U1 & U2 & U3 & U4 & U5 & \\
\hline & & & $\ldots \% \ldots$ & & \\
P0 & 27,24 & 29,64 & 25,17 & 22,98 & 25,35 & $26,08 \pm 2,50$ \\
P1 & 24,98 & 23,47 & 28,27 & 27,25 & 31,99 & $27,19 \pm 3,28$ \\
P2 & 26,97 & 28,00 & 26,01 & 28,87 & 27,10 & $27,39 \pm 1,09$ \\
P3 & 28,13 & 26,31 & 26,24 & 21,99 & 26,52 & $25,84 \pm 2,29$ \\
\hline Probabilitas & & & & & & 0,67
\end{tabular}

Keterangan : $\mathrm{PO}=0 \%$ pemberian tepung daun katuk (kontrol), $\mathrm{P} 1=4 \%$ pemberian tepung daun katuk, P2 = 8\% pemberian tepung daun katuk, P3 = 12\% pemberian tepung daun katuk

Tabel 7. Pengaruh pemberian tepung daun katuk terhadap drip loss

\begin{tabular}{ccccccc}
\hline \multirow{2}{*}{ Perlakuan } & U1 & U2 & Ulangan & \multirow{2}{*}{ Rata-Rata \pm Sd } \\
\cline { 2 - 5 } & \multicolumn{7}{c}{$\ldots \% \ldots$} & U4 & U5 & \\
\hline P0 & 6,59 & 6,43 & 5,72 & 5,61 & 7,63 & $6,40 \pm 0,81$ \\
P1 & 4,60 & 6,23 & 6,59 & 7,18 & 7,92 & $6,51 \pm 1,24$ \\
P2 & 9,56 & 5,63 & 6,79 & 5,40 & 7,20 & $6,92 \pm 1,66$ \\
P3 & 6,18 & 7,89 & 6,38 & 6,87 & 7,70 & $7,0 \pm 0,77$ \\
\hline
\end{tabular}

Probabilitas

PO $=0 \%$ pemberian tepung daun katuk (kontrol), $\mathrm{P} 1=4 \%$ pemberian tepung daun katuk, P2 $=8 \%$ pemberian tepung daun katuk, P3 $=12 \%$ pemberian tepung daun katuk

Meat Bone Ratio dipengaruhi oleh beberapa faktor yaitu pakan, spesies, bangsa, umur, dan jenis kelamin (Soeparno, 2015). Dewi (2010) menyatakan bahwa produksi daging, tulang, dan bagian-bagian tubuh yang lainnya dari ayam kampung umur 2-10 minggu, tumbuh dengan kecepatan yang berbeda sesuai dengan meningkatnya umur.

\section{Cooking Loss}

Hasil analisis pengaruh pemberian tepung daun katuk terhadap cooking loss ayam kampung disajikan pada Tabel 6.

Hasil analisis ragam menunjukkan pemberian tepung daun katuk tidak berpengaruh nyata terhadap cooking loss $(P>0.05)$. Rataan nilai cooking loss perlakuan P0, P1, P2 dan P3 masing-masing 26,08\%, $27,19 \%, 27,39 \%$, dan $25,84 \%$. Protein yang digunakan dalam penelitian ini tidak berbeda sehingga cooking loss yang dihasilkan tidak berbeda antar perlakuan.

Tingginya kadar protein daging berpengaruh terhadap cooking loss, karena protein mempunyai kemampuan untuk mengikat air dalam daging (Suradi, 2006).

Kartikasari et al. (2018) menyatakan bahwa salah satu faktor penyebab hilangnya jumlah air selama pemasakan adalah protein daging yang dapat mengikat air, dengan demikian semakin banyak air yang ditahan oleh protein daging maka semakin sedikit air yang terlepas dan menghasilkan susut masak yang lebih rendah. Nurkhasanah (2015) menyatakan bahwa pemberian ekstrak daun katuk dan tepung kunyit berpengaruh tidak nyata terhadap cooking loss ayam broiler. Dewayani et al. (2015) menyatakan bahwa susut masak dipengaruhi oleh nilai $\mathrm{pH}$, panjang sarkomer serabut otot, panjang potongan serabut otot, status kontraksi miofibril, ukuran dan berat sampel, penampang melintang daging, pemanasan, bangsa terkait lemak daging, umur, dan konsumsi energi dalam pakan.

Hasil analisis sidik ragam menunjukan bahwa penggunaan tepung daun katuk dalam ransum berpengaruh tidak nyata terhadap drip loss $(P>0,05)$. Rataan drip loss ayam kampung perlakuan P0, P1, P2, P3 dan P4 
sebesar 6,40 \%, 6,50 \%, 6,92\% dan 7,03 \%. Salah satu faktor yang dapat mempengaruhi drip loss adalah kadar protein dimana protein dalam pakan yang diberikan pada setiap perlakuan reltif sama, sehingga drip loss antar perlakuan relatif sama. Hasil analisis pengaruh pemberian tepung daun katuk terhadap drip loss ayam kampung disajikan pada Tabel 7 .

Banes et al. (2017) menyatakan bahwa nilai kisaran drip loss pada ayam broiler yang diberikan pemberian ekstrak daun katuk fermentasi 3,39\% - 5,74\%. Qotimah et al (2014) menyatakan bahwa rataan drip loss pemberian ekstrak daun katuk terhadap ayam broiler menunjukkan hasil pada pemberian pada 4,5 g didapat nilai drip loss $7,50 \%$ dan pemberian $9 \mathrm{~g}$ didapat nilai drip loss $9,02 \%$.

\section{Drip Loss}

Drip loss merupakan salah satu pengukuran daya ikat air yang memiliki prinsip air bebas akan dilepaskan dari protein otot dan sejalan dengan penurunan $\mathrm{pH}$ otot (Lukman et al., 2008). Santoso (2014) menyatakan daya mengikat air pada daging biasanya dipengaruhi oleh protein daging itu sendiri, dimana semakin tinggi protein dalam daging maka kemampuan mengikat air juga akan semakin meningkat sehingga cairan yang keluar selama proses pelayuan akan lebih sedikit.

\section{KESIMPULAN}

Pemberian tepung daun katuk sampai level $12 \%$ tidak dapat memperbaiki mutu karkas ayam kampung betina.

\section{UCAPAN TERIMA KASIH}

Ucapan terima kasih penulis sampaikan kepada Kementrian Pendidikan Dan Kebudayaan serta Universitas Bengkulu, cq.Lembaga Penelitian dan Kepada Masyarakat karena penelitian ini merupakan bagian dari Penugasan Perlaksanaan Penelitian Percepatan Guru Besar tahun anggaran 2020 dengan nomor kontrak: 2074/UN30.15/PG/2020 tanggal 23 Juni 2020.

\section{DAFTAR PUSTAKA}

Adnyana. I. G. S., G. A. M. K. Dewi, dan M. Wirapartha. 2014. Pengaruh imbangan energi dan protein ransum terhadap karkas ayam kampung betina umur 30 minggu. Peternakan Tropika 2(3): 415 - 424

Agustal, A., M. Harapini dan Chairul. 1997. Analisis kandungan kimia ekstrak daun katuk (Sauropus androgynus (L) Merr) dengan GCMS. Warta Tumbuhan Obat Indonesia 3(3): 31-33.

Ahmad, B dan R. Herman. 1982. Perbandingan Produksi Daging Antara Ayam Jantan Kampung dan Ayam Jantan Petelur. Media Peternakan (25) 3-6.

Azis, S. dan S. R Muktingsih. 2006. Studi manfaat daun katuk (Sauropus androgynus). cermin dunia kedokteran. pusat penelitian dan pengembangan farmasi. Badan Penelitian dan Pengembangan Kesehatan. Departemen Kesehatan Republik Indonesia. Jakarta 151: 48-50.

Banes, S. S., Kususiyah dan Y. Fenita. 2017. Pengaruh ekstrak daun katu (Sauropus androgynus) fermentasi terhadap kualitas karkas broiler. Jurnal Sain Peternakan Indonesia. 12(2):199-208.

Bidura, I.G.N.G., D.P.M.A. Candrawati dan N.L.G. Sumardani. 2007. Pengaruh penggunaan daun katuk (Saurupus androgynus) dan daun bawang putih (Allium sativum) dalam ransum terhadap penampilan ayam broiler. Majalah Peternakan, Vol 10: 1-11.

Dewayani, R. E., N. Halim dan S. Osfar. 2015. Pengaruh penggunaan onggok dan ampas tahu terfermentasi mix cultureaspergillus niger dan rhizopus oligosporus sebagai pengganti jagung dalam pakan terhadap kualitas fisik dagingayam pedaging. Bagian Nutrisi dan Makanan Ternak. Jurnal IImu dan Teknologi Hasil Ternak. 10:9-17.

Dewi, G. A. M. K. 2010. Pengaruh penggunaan level energi - protein ransum terhadap produksi karkas ayam kampung. Prosiding Seminar Nasional Tentang Unggas Lokal ke IV. Hal; 222-228 
Kartikasari, L.R., S.H. Bayu., S. Iwan dan M.P.N. Adi. 2018. Kualitas fisik daging ayam broiler yang diberi pakan berbasis jagung dan kedelai dengan suplementasi tepung purslane (Portulaca Oleracea). Jurnal Teknologi Pangan. 12(2) : 64-71.

Lukman, D.W., M. Sudarwanto, A.W. Sanjaya, T. Purnawarman, H. Latif dan R.R. Soejoedono. 2012. Penuntun Praktikum Hiegene Pangan Asal Hewan. Bagian Kesehatan Masyarakat Veteriner. Fakultas Kedokteran Hewan. Institut Pertanian Bogor. Bogor.

Letis, Z.M. 2016. Khasiat berbagai sediaan katuk (sauropus androgynus L.) dalam memperbaiki produktivitas, kualitas daging, dan profil hematologi ayam broiler. Skripsi. Institut Pertanian Bogor. Bogor.

Marsetyo., N. Marfuah dan Hafsah .2015. Pengaruh level penggunaan daun katuk (Saoropus androgynus) pada ransum terhadap penampilan produksi dan persentase karkas ayam kampung. Online Jurnal of Natural Science. 4(1):73-83

Matitaputty, P.R., R, R Noor., P.S Hardjosworo dan C.H Wijaya. 2011. Performa, persentase karkas dan nilai heterosis itik alabio, cihateup dan hasil persilangannya pada umur delapan minggu. Jurnal Ilmu Ternak dan Veteriner. 16:90-98.

Nurkhasanah, B. 2015. Pengaruh suplementasi ekstrak daun katu (Sauropus androgynus) dan tepung kunyit (Curcuma domestica) terhadap kualitas karkas ayam broiler yang diberi pakan berprotein rendah. Skripsi. Fakultas Pertanian, Universitas Bengkulu, Bengkulu

Qotimah, S., U. Santoso, dan E. Soetrisno. 2014. Pengaruh level protein dan suplementasi ekstrak daun katu (Sauropus androgynus) terhadap kualitas karkas broiler. Jurnal Sain Peternakan Indinesia. 9(2):130-136.

Rasyaf, M. 2006. Beternak Ayam Pedaging. Penebar Swadaya, Jakarta.

Santoso, U. 2014. Katuk,Tumbuhan Multi Khasiat. Badan Penerbit Fakultas Pertanian (BPFP) UNIB. Bengkulu.

Santoso, U., Y. Fenita, Kususiyah, dan I. G. N. G. Bidura. 2015. Effect of Fermented Sauropus androgynus Leaves on Meat Composition,Amino Acid and Fatty Acid Compositions in Broiler Chickens. Pakistan Journal of Nutrition 14 (11): 799-807. 2015.

Saputro, L. 2019. Pengaruh penggunaan tepung daun senduduk (Melastoma Malabathricum L.) dalam ransum terhadap kualitas karkas ayam buras. Skripsi. Universitas Bengkulu. Bengkulu.

Subekti, S. 2003. Kualitas telur dan karkas ayam lokal yang diberi tepung daun katuk dalam ransum. Tesis. Program Pascasarjana IPB. Bogor.

Suprayogi A. 2000. Studies on the biological effect of Sauropus androgynus (L) Merr: Effect on milk production and the possibilities of induced pulmonary disorder in lactating sheep [Disertation]. Berlin (Germany): University of Gottingen

Syahruddin E. 2002. Penggunaan eceng gondok fermentasi dalam ransum terhadap kandungan kolesterol dan sistem pencernaan ayam broiler. Peternakan dan Lingkungan. 8:02.

Tamzil M.H., M. Ichsan., N.S. Jaya., and M. Taqiuddin. 2015. growth rate, carcass weight and percentage weight of carcass parts of laying type cockerels, kampong chicken and arabic chicken in different ages. Pak J Nutr.14 : 377-382. 